\title{
A Comparison of Online Games and Pictures Instruction in the Context of EFL to Enhance Students' Vocabulary Achievement
}

\author{
Beauty Gatari Cathleen Wenas and Caroline V. Katemba Tobing \\ Fakultas Keguruan dan Ilmu Pendidikan, Universitas Advent Indonesia \\ Telp/Fax: +62 (022) 2700247 \\ J1. Kol. Masturi No. 228 Parongpong, Bandung 40559, INDONESIA \\ Email : beautyuty18@yahoo.co.id
}

\begin{abstract}
The purpose of this study is to find the enhancement of students' vocabulary achievement using Online Games and Pictures Instruction. This study used quantitative research method and comparative design. This study was designed to seek the answer to the following question: Is there any significant difference on the students' vocabulary enhancement between those who are taught using Online Games and Pictures Instruction? In order to answer that question, there were two classes in grade eight of SMP Perguruan Advent XV Ciracas, Jakarta Timur. They were divided into two groups, grade 8-a was Pictures Instruction group and grade 8-b was Online Games group. The vocabulary test (pre-test) was given at the first meeting. After 16 hours of treatment, the post-test was administered to both groups to see the significant of both methods. The data was analyzed using SPSS 17. The normalized gain of the students who are taught using Online Games 0.2802. It can be concluded that the gain level of Online Games is low. While the normilezed gain of the students who are taught using Pictures Instruction is 0.4631 . It can be concluded that the gain level of it can be concluded that the gain level of Picture Instruction is average. The obtained result through the normalized gain indicated there was a significant difference between the group which was taught through Online Games and Pictures Instruction.
\end{abstract}


Based on the result of the data the null hypothesis was rejected and some recommendations are given at the end.

Key Word: vocabulary, teaching, Online Games, Picture Instruction

\section{INTRODUCTION}

In this era of technology everything is associated with gadget. Well, the children having their own gadget such as computer, smartphone, laptop, tab, etc. Some of those stuff provided by parents since their early age. One of the most popular activities done by children under the age of 17 are playing online games. The curriculum used today is based on competence.

Education based on competence is education that emphasizes the ability to be possessed by graduates of a given education level. It means students are required to have certain competencies or skills as a result of the learning process in schools. To compete in a global world, the competence or the ability of the main assets that must be owned by the students. Therefore it is expected that a competency-based curriculum can produce students who can compete globally. But some schools have difficulty in achieving basic competency in English language lesson. This is because the lack of mastery of the English language vocabulary. Students often have difficulty understanding the meaning of a word for the understanding of their relatively inadequate vocabulary so that the process of achieving a basic competency will be longer.

This study offer a new method to teach vocabulary through online games. Because today many children are addicted to playing online games. Turgut and Irgin (2009) said that learning via computer games can be considered as surreal and outrageous. Many people are troubled with the themes that constitute certain games, and concerned with the intensity of involvement and amount of time that youth 
devote to playing computer games. In this case the researcher sees this online games can also be used as a tool for learning English. According to Jan (2013) and Thomas \& Brown (2011), learning through games is one of the most effective ways to learn, because games are used to improve content mastery, higher-order thinking skills, and social skills during the learning process. The uptake and use of games in educational and training contexts indicate a significant level of interest in game-based activities (De freitas \& Griifiths, 2008). Processes of language learning have become more engaging by means of educational games which are believed to add fun to classrooms where students would feel more relaxed and comfortable. This study seeks to find out the effect of online games in enhance the ability of students vocabulary that compared with the picture instruction method. These things needed for enhancing student vocabulary ability.

\section{EXPERIMENTAL}

\section{Population and Sample}

The participants of this study were the pupils of SMP Perguruan Advent XV Ciracas, East Jakarta, Jakarta. They were divided into two groups. Grade 8A and 8B consist of 56 students of SMP Advent Ciracas in East Jakarta. None of the participants had any experience of participating in this kind of experiments.

\section{Research Instrument}

The instrument used in gathering the data was vocabulary test. It is used to measure pupils' comprehension of their vocabulary. The instrument used in the treatment method are computer's laboratory, Wi-Fi, pictures that captured from the online game, online game, LCD-projector. The test was administered at the beginning and before the treatment is administered and a post test administered at the end of 16 
hours treatment to find out the pupils' achievement in vocabulary using online games and Pictures instruction.

\section{Treatment}

Procedures of Online Games:

- Teacher gave some new words with a broad application domain in game nets or online games were selected to be presented to the students' application domain in game nets. Online games are selected to be presented. Teacher told the kinds of the game online that student can play and explain to them step by step on playing the online game.

- Students are allowed to use the internet in the classroom where they could play online games.

- During the class time students in the online games group enjoyed an enjoyable environment where they used a variety of words in the context.

- Students wrote the vocabulary that they recently learn.

- Teacher give test about the vocabulary that student recently know.

Procedures of Pictures Instruction:

- Teacher introduced the lesson to the student

- Teacher gave pictures to the student using Power-point Presentation with the English word that describes the pictures.

- After the presentation the students in each group practiced the words through repetitions and question-answer drills using the same mode of instruction used to present new items in the class.

- Teacher gave students worksheet about the PicturesTeacher introduced the lesson to the student. 


\section{Data Gathering}

- Pilot test

Data collection instrument was preceded by pilot studies in children who are part of the student population not sample. That is to determine whether the instrument is sufficiently reliable or not, communicative, understandable, and so on.

- Pretest

The pretest for the grade 8A and 8B pupils administered on February 1, 2016. It is consist of 30 and design in form of multiple-choice questions.

- Post Test

After the treatment student was given a post-test. The post-test found out whether the use of Online Game and Pictures Instruction make impact on the students' vocabulary improvement.

- Validity of test question

Validity test was intended to find out wheatear the instrument test is appropriate to be used in this research or not.

$$
r_{x y}=\frac{n \sum_{i=1}^{n} X_{1} Y_{1}-\sum_{i=1}^{n} X \sum_{i=1}^{n} Y}{\sqrt{\left\{n \sum_{i=1}^{n} y_{i}^{2}-\left(\sum_{i=1}^{n} y_{i}\right)^{2}\right\}\left\{n \sum_{i=1}^{n} y_{i}^{2}-\left(\sum_{i=1}^{n} y_{i}\right)^{2}\right\}}}
$$

The result of the statistical computation on the pilot-test is presented in the following table. 
Table 1.1 Classification of Validity Question

\begin{tabular}{|l|l|l|}
\hline Number of Question & Rxy & Interpretation \\
\hline $3,6,18,21,28,36,43,45=8$ & $0.40<r_{x y} \leq 0.60$ & Moderate \\
\hline $\begin{array}{l}2,4,7,11,12,13,14,15,17,19,26,27,30,32, \\
35,39,41,42,44\end{array}$ & $0.20<r_{x y} \leq 0.40$ & Low \\
\hline $\begin{array}{l}5,8,9,10,20,22,23,25,29,33,34,37,38,40, \\
46,49\end{array}$ & $0.00<r_{x y} \leq 0.20$ & Very Low \\
\hline $1,16,24,31,48,47$ & $\leq 0.00$ & \\
\hline
\end{tabular}

Questions are valid if the score is larger than 0.00. Based on the result of the table calculation above there were 44 questions that were valid. There were 4 questions that were not valid, 16 questions were very low, 20 questions were low and 8 questions were moderate. The result of the table above showed that there were 20 items that had raw score $0.20-0.40$. So, it can be concluded that the validity was low.

- Reliability Test

Reliability is the constant of a test when the test is done in the same subject.

$$
r_{11}=\left(\frac{n}{n-1}\right)\left(\frac{s^{2}-\sum p q}{s^{2}}\right)
$$

Arikunto (2012) 
Table 1.2 Classification of Reliability Test

\begin{tabular}{|l|l|}
\hline $\begin{array}{l}\text { Coefficient of } \\
\text { Reliability }\end{array}$ & Interpretation \\
\hline $0.90<r_{11} \leq 1.00$ & Very High \\
\hline $0.70<r_{11} \leq 0.90$ & High \\
\hline $0.40<r_{11} \leq 0.70$ & Moderate \\
\hline $0.20<r_{11} \leq 0.40$ & Low \\
\hline$r_{11} \leq 0.20$ & Very Low \\
\hline
\end{tabular}

The result of the computation of reliability test showed that the reliability is 0,60 . It can concluded that reliability of the test was moderate.

- Discrimination Index of Question

The discrimination index of item is the ability to distinguish between good student (high ability) and the students who are less in intelligent (low ability).

$$
D=\frac{B_{A}}{J_{A}}-\frac{B_{B}}{J_{B}}=P_{A}-P_{B}
$$

(Arikunto, 2012)

The result of statistical computation on the pilot test is presented in the following table. 
Table 1.3 Result of Discrimination level of Question

\begin{tabular}{|l|l|l|}
\hline Number of Question & Discrimination index & Interpretation \\
\hline 3 & $0.70-1.00$ & Excellent \\
\hline $4,6,19,21,28,36,43,45$ & $0.40-0.70$ & Good \\
\hline $\begin{array}{l}14,15,18,20,25,26,27,30,32,37,38, \\
40,41,42\end{array}$ & $0.20-0.40$ & Satisfactory \\
\hline $\begin{array}{l}1,2,5,8,9,10,17,22,23,29,33,34,35, \\
44,47,48,49\end{array}$ & $0.00-0.20$ & \\
\hline $16,24,31,39,46$ & $<0.00$ & Poor \\
\hline
\end{tabular}

The result of the table above showed that there are 17 items with discrimination index between $0.00-0.20$. It can be concluded that the discrimination index of the test is poor.

- Statistical Treatment Data

The researcher used the t-test to find out whether the achievement of the pupils who are taught by using Online Games is different from those who were taught by Pictures Instruction. To examine the data, the researcher compared means of the test between two independent data group which is done by using statistical or t-test. 


\section{RESULTS AND DISCUSSIONS}

\section{Result of Data Analysis}

In gathering data of the research, the researcher taught two classes at SMP Perguruan Advent XV Ciracas, one class was Online Games group and the other class was Pictures Instruction group. The following table is the result of pre-test and post-test of each group.

Table 1.4 Result of Pre-test, Post-test, Standard Deviation and Normalized Gain

\begin{tabular}{|l|l|l|l|l|}
\hline \multirow{2}{*}{} & \multicolumn{2}{|l|}{ Online Games } & \multicolumn{2}{l|}{ Pictures Instruction } \\
\cline { 2 - 5 } & Mean & St. Deviation & Mean & St. Deviation \\
\hline Pre-test & 60.31 & 11.390 & 58.93 & 12.128 \\
\hline Post-test & 71.35 & 12.903 & 77.33 & 11.025 \\
\hline Normalized Gain & 0.2802 & 0.25763 & 0.4631 & 0.18223 \\
\hline
\end{tabular}

Based on the result of the table above showed that the mean and standard deviation in students' vocabulary achievement, it has gained 0.2802 and the mean of the students who were taught using Online Games 60.31 and the post-test is 71.35 , while the gain of the students who are taught using Pictures Instruction is 0.4631 . The mean in pre-test is 58.93 and the post-test is 77.33. The standard deviation for each group in SPSS 17, the standard deviation result of Online Games group is 0.25763 , while the standard deviation of Pictures Instruction group is 0.18223 . 


\section{Test of Normality}

The researcher is using the test of normality to observe probability distribution of the data.

Table 1.5 Result of Normalized Gain

\begin{tabular}{|ll|l|l|l|}
\hline \multirow{2}{*}{} & \multirow{2}{*}{ Group } & \multicolumn{2}{|l|}{ Shapiro-Wilk } \\
\cline { 2 - 4 } & Statistic & df & Sig. \\
\hline Gain & Gain PI & .954 & 30 & .214 \\
& Gain OG & .981 & 26 & .887 \\
\hline
\end{tabular}

Based on the table above, this reseach used the output from the Shapiro-Wilk because Shapiro-Wilk is the most powerful normality test and because the test is originally restricted for sample size of less than 50 (Razali \& Wah, 2011). If both data have $\rho$ value ( $\operatorname{sig})>\alpha=0.05$ it means data is normally distributed and if $\rho$ value (sig) $<$ $\alpha=0.05$, it means data is not normally distributed. Based on the data above, both data was normally distributed because the significant score of gain for Online Games was (sig) $0.887>\alpha=0.05$ and the significant of the normalized gain for Pictures Instruction was ( $\mathrm{sig}$ ) $0.214>\alpha=0.05$.

\section{Test of Homogeneity of Variance}

Based on statistic if both of the data were normally distributed, then the data homogeneity test was used. 


\section{Table 1.6 Result of Homogeneity of Variance}

Gain
\begin{tabular}{|l|l|l|l|}
\hline $\begin{array}{l}\text { Levene } \\
\text { Statistic }\end{array}$ & df1 & df2 & Sig. \\
\hline 3.432 & 1 & 54 & .069 \\
\hline
\end{tabular}

The data is homogenous if $\rho$ value (sig) $>\alpha=0.05$ it means data is homogenous and if $\rho$ value (sig) $<\alpha=0.05$, it means data is not homogenous. Based on the result of the table above, the result of the data between Online Games and Pictures Instruction were homogenous because Sig $(0.069)>\alpha=0.05$. 


\section{Hypothesis Testing}

Table 4.4 Independent Samples Test

\begin{tabular}{|c|c|c|c|c|c|c|c|c|c|c|}
\hline \multicolumn{11}{|c|}{ Independent Samples Test } \\
\hline & & \multicolumn{2}{|c|}{$\begin{array}{l}\text { Levene's } \\
\text { Test for } \\
\text { Equality of } \\
\text { Variances }\end{array}$} & \multicolumn{7}{|c|}{ t-test for Equality of Means } \\
\hline & & \multirow[t]{2}{*}{$\mathrm{F}$} & \multirow[t]{2}{*}{ Sig. } & \multirow[t]{2}{*}{$\mathrm{t}$} & \multirow[t]{2}{*}{$\mathrm{df}$} & \multirow[t]{2}{*}{$\begin{array}{l}\text { Sig. } \\
\text { (2- } \\
\text { taile } \\
\text { d) }\end{array}$} & \multirow[t]{2}{*}{$\begin{array}{l}\text { Mean } \\
\text { Differ } \\
\text { ence }\end{array}$} & \multirow[t]{2}{*}{$\begin{array}{l}\text { Std. } \\
\text { Error } \\
\text { Diffe } \\
\text { rence }\end{array}$} & \multicolumn{2}{|c|}{$\begin{array}{l}95 \% \\
\text { Confidence } \\
\text { Interval of } \\
\text { the } \\
\text { Difference }\end{array}$} \\
\hline & & & & & & & & & $\begin{array}{l}\text { Lowe } \\
\text { r }\end{array}$ & $\begin{array}{l}\text { Upp } \\
\text { er }\end{array}$ \\
\hline Gain & $\begin{array}{l}\text { Equal } \\
\text { varianc } \\
\text { es } \\
\text { assume } \\
\text { d }\end{array}$ & $\begin{array}{l}3.43 \\
2\end{array}$ & $\begin{array}{l}.06 \\
9\end{array}$ & $\begin{array}{l}3.09 \\
7\end{array}$ & 54 & $\begin{array}{l}.00 \\
3\end{array}$ & $\begin{array}{l}.1828 \\
9\end{array}$ & $\begin{array}{l}.0590 \\
5\end{array}$ & $\begin{array}{l}.0645 \\
1\end{array}$ & $\begin{array}{l}.301 \\
27\end{array}$ \\
\hline
\end{tabular}

According to the data above, the researcher used the data of equal variances assumed concern that the sample data was distributed homogenous and sig (2-tailed). Based on the result of the data sig (2 tailed), it shown that sig. $(0.003) \leq \alpha(0.05)$, it means that $\mathrm{Ha}$ is accepted and Ho is rejected. For that researcher concluded there is significant difference between those who were taught through Online Games and those who were taught through Picture Instruction.

Based on the result of this study online games have significant result because through online games that students can learn vocabulary without feeling stress to 
memorize. With a good atmosphere and fun, students unconsciously forcing themselves to understand the words that exist in the online game. and the result of this study was also supported by research of Purushotma (2005) who has suggested that games can be so highly motivating that even addictive they become so engaged in game activities that they stay in the classroom even in the break time. Rivalry and fun go together, creating both a friendly and competitive environment.

For the treatment of Pictures Instruction, there is also significant result because the images have appealed and have a permanent effect when students learn vocabulary. Pictures also help students memorized the new words and help teachers to make lesson more interesting. Colored images make students more interested in learning the language. this study was also supported by Mansourzadeh (2015) who mentioned that pictures are those kinds of visual instruction materials that can be used more effectively to develop and sustain motivation in producing positive attitudes towards English and to teach or reinforce language skills.

Based on the results of the two methods of learning, the mean of the picture has a higher score than the mean of the online games. This could be due to the method which has been frequently used by teachers in introducing new vocabulary to students that use the images as a tool. Since the beginning students learn the English language, is frequently used media images. In terms of textbooks also may be seen that the textbooks of English in Indonesia using a variety of images.

\section{Conclusion}

From the result of the data analysis based on the normalized gain from the pre-test and post-test, the enhancement of EFL students' vocabulary achievement for Online Games and Pictures Instruction class were average. Based on the research finding, the researcher can concludes that there is significant difference in the enhancement of students' vocabulary achievement in English between those who were taught using Online Games and Pictures Instructions. 


\section{References}

de Freitas, S. and Griffiths, M. (2008). The Convergence of Gaming Practices with Other Media Forms: What Potential for Learning? A Review of the Literature.

Learning, Media and Technology, 33(1), 11-20.

Jan, M. (2013). A literature review of game-based learning. Singteach, 45. Retrieved from

http://singteach.nie.edu.sg/ issue45-research02/

Purushotma, R. (2005). Commentary: You're not studying, you're just ... Language Learning \& Technology, 9(1), 80-96.

Mansourzadeh, N. (2015). A comperative study of teaching vocabulary through pictures and audio-visualaids to young Iranian EFL learners. Journal of Elementary Education Vol.24, No. 1 pp. 47-5.9

Thomas, D., \& Brown, J. S. (2011). A new culture of learning cultivating the imagination for a world of constant change. Lexington, KY: CreateSpace.

Turgut,Y. \& Irgin, P. (2009). Young Learners' Language Learning Via Computer Games. 